\title{
16
}

\section{WASTE MANAGEMENT POLICY IN LITHUANIA}

\author{
Irena Gaveniene \\ Environmental Protection Ministry \\ of the Republic of Lithuania
}

According to statistical data 6 million tones of waste have formed in Lithuania during 1996: 101 thousand tones hazardous waste - 60 thousand of which are oily and water emulsion waste. Non-hazardous waste has formed 4.5 million tones: 1.5 million tones are household waste. So, waste management problems become more and more important and priority in Lithuania. The highest threat to humans and the environment is rising from hazardous waste, 150 thousand tones per year of which forms in Lithuania. The biggest amounts of hazardous waste form in the industrial plants of Siauliai, Vilnius, Klaipeda and Kaunas regions.

The Government have adopted Program of Hazardous Waste management in 1996, but cost for the implementation of the programme (100 million USD) are too high for Lithuania. After the evaluation of funds needed for construction of incineration plant of hazardous waste it became clear that it is not real to build it up, so it is necessary to find alternative ways for the management of hazardous waste. It will be constructed and intalled collection, handling and treatment plants or grounds in six regions: Vilnius, Klaipeda, Siauliai, Panevezys, Alytus, Kaunas and it will be possible to handle hazardous waste in a safe way and to implement the control of hazardous waste management. During 1993-1996, using minimal State budget resources (159 thousand Lt in 1993, 601.6 thousand Lt in 1994, 500 thousand Lt in 1996) 5 grounds were designed for hazardous waste handling, selected sites for construction of grounds for handling of hazardous waste in Siauliai, Klaipeda, Alytus, Vilnius and Panevezys and construction works of grounds in Siauliai and Klaipeda have started. The projects for construction of three grounds were included into the State Investment Program and presented for foreign investors. The Project for Klaipeda hazardous waste ground was presented to EU PHARE CROSS BORDER for grant. 
The item of management of some hazardous waste (banned and not suitable for using pesticides (BNSP) shall be solved as soon as possible. There are 6000 tones of such waste. Environmental Protection Ministry has prepared and submitted to the Government the Program for Management of BNSP in 1997 in which necessary funding and terms of reference are foreseen. The State budget $(2$ million $\mathrm{Lt}$ ) and Environmental Protection Funds of Municipalities will be used to solve the problem in 1997. At present medical waste management system in Lithuania with support of Danish specialists is under preparation and this system will be part of an integrated hazardous waste management system. The prefeasibility studies for collection and management of medical waste were prepared for approval in 1996. This job is organised by the Ministries of Health and Economy together with the Ministry of Environmental protection.

There is a plan to prepare such a program in 1997.

The applying into practice the European Unity Directives and regulatory measure is useful for organising in proper way the management of wastes, selection of household waste and using of second stuff. At present taking into account experience of developed countries and especially experience of Denmark the Waste Act is under preparation.

The solution of waste management problem will speed up Hazardous Waste Management Study started in 1997 and funded by EU PHARE program (300 thousand ECU). The purpose of the study is to prepare National Hazardous Waste Management Strategy. 